OPEN ACCESS

Edited by:

Orsolya Valkó,

Hungarian Academy of Science,

Hungary

Reviewed by:

Shanjia Li,

Lanzhou University of Technology,

China

Ning Chen,

Lanzhou University, China

*Correspondence:

Jianjun Cao

caoj@nwnu.edu.cn

Specialty section:

This article was submitted to

Conservation and Restoration

Ecology,

a section of the journal

Frontiers in Environmental Science

Received: 30 October 2021

Accepted: 27 December 2021

Published: 01 February 2022

Citation:

Su H, Cui J, Adamowski JF, Zhang X Biswas A and Cao J (2022) Using Leaf Ecological Stoichiometry to Direct the Management of Ligularia virgaurea on the Northeast Qinghai-Tibetan Plateau.

Front. Environ. Sci. 9:805405.

doi: 10.3389/fenvs.2021.805405

\section{Using Leaf Ecological Stoichiometry to Direct the Management of Ligularia virgaurea on the Northeast Qinghai-Tibetan Plateau}

\author{
Haohai $\mathrm{Su}^{1,2}$, Jiabao Cui ${ }^{1}$, Jan F. Adamowski ${ }^{3}$, Xiaofang Zhang ${ }^{4}$, Asim Biswas ${ }^{5}$ and \\ Jianjun $\mathrm{Cao}^{1,2 *}$
}

${ }^{1}$ College of Geography and Environmental Science, Northwest Normal University, Lanzhou, China, ${ }^{2}$ Key Laboratory of Resource Environment and Sustainable Development of Oasis, College of Geography and Environmental Science, Northwest Normal University, Lanzhou, China, ${ }^{3}$ Department of Bioresource Engineering, Faculty of Agricultural and Environmental Sciences, McGill University, Montreal, QC, Canada, ${ }^{4}$ Key Laboratory of Eco-hydrology of Inland River Basin, Northwest Institute of Eco-

Environment and Resources, Chinese Academy of Sciences, University of Chinese Academy of Sciences, Lanzhou, China,

${ }^{5}$ School of Environmental Sciences, University of Guelph, Guelph, ON, Canada

Leaf ecological stoichiometry not only reflects the plasticity and adaptability, but also the growth of plants within environments where temperature, precipitation, and soil properties vary across an elevation gradient. Ligularia virgaurea (Maxim.) Mattf. ex Rehder \& Kobuski - an invasive poisonous plant - is common in the northeast portion of China's QinghaiTibetan Plateau and its presence greatly affects the native ecosystem. Based on $L$. virgaurea leaf carbon $\left([\mathrm{C}]_{\text {leaf }}\right)$, nitrogen ( $[\mathrm{N}]_{\text {leaf }}$ ) and phosphorus $\left([\mathrm{P}]_{\text {leaf }}\right)$ concentrations, and their ratios, the species' coping strategies across an elevation gradient $(2,600 \mathrm{~m}, 3,000 \mathrm{~m}$, and $3,300 \mathrm{~m}$ ) were identified, and served to inform the development of improved management strategies. Mean $[\mathrm{C}]_{\text {leaf }},[\mathrm{N}]_{\text {leaf }}$ and $[\mathrm{P}]_{\text {leaf }}$ in $\mathrm{L}$. virgaurea across all elevations were $413.14 \mathrm{~g} \cdot \mathrm{kg}^{-1}, 22.76 \mathrm{~g} \cdot \mathrm{kg}^{-1}$, and $1.34 \mathrm{~g} \cdot \mathrm{kg}^{-1}$, respectively, while $[\mathrm{C}]_{\text {leaf: }}$ : $[\mathrm{N}]_{\text {leaf }},[\mathrm{C}]_{\text {leaf: }}[\mathrm{P}]_{\text {leaf, }}$ and $[\mathrm{N}]_{\text {leaf: }}[\mathrm{P}]_{\text {leaf }}$ were $18.27,328.76$, and 17.93. With an increase in precipitation and decrease in temperature from $2,600 \mathrm{~m}$ to $3,000 \mathrm{~m}-3,300 \mathrm{~m}$, [C] leaf, $[C]_{\text {leaf: }}[\mathrm{N}]_{\text {leaf }}$ and $[\mathrm{C}]_{\text {leaf: }}[\mathrm{P}]_{\text {leaf }}$ of $L$. virgaurea decreased at first and then increased. The $[\mathrm{N}]_{\text {leaf }}$ and $[\mathrm{P}]_{\text {leaf }}$ gradually increased, whereas $[\mathrm{N}]_{\text {leaf: }}[\mathrm{P}]_{\text {leaf }}$ showed little change. Although temperature, precipitation and soil water content were the main factors affecting the ecological stoichiometry of $L$. virgaurea leaves, their roles in influencing leaf elements were different. The $[\mathrm{C}]_{\text {leaf }}$ was mainly influenced by soil water content, $[\mathrm{N}]_{\text {leaf }}$ by temperature and soil water content, and $[\mathrm{P}]_{\text {leaf }}$ by all of them. With potential future climate change in the study area, $L$. virgaurea may grow faster than at present, although soil $P$ may still be a growth-limiting element. As $L$. virgaurea can reduce plant diversity and the quality of forage, while increasing biomass, management of $L$. virgaurea should receive greater attention.

Keywords: toxic weeds, alpine region, elevation, plant element concentration, warming 


\section{INTRODUCTION}

Invasion by toxic weeds has become one of the critical causes of serious grassland degradation around the world (Goslee et al., 2001; Kleijn and Müller-Schärer, 2006; Timsina et al., 2011). Occupying over $60 \%$ of the total area of the QinghaiTibetan Plateau (QTP), alpine grasslands constitute a biome widely reported to be sensitive to human activities and climate change (Wu et al., 2012; Bakhshi et al., 2019). In recent years, in addition to Ligularia virgaurea (Maxim.) Mattf. ex Rehder \& Kobuski, an increase in other poisonous and weedy plants (e.g., Stellera chamaejasme L., Thermopsis lanceolata R.Br., Oxytropis ochrocephala Bunge, Gentiana straminea Maxim., and Potentilla bifurca L.) has exacerbated grassland degradation on the QTP (Wu et al., 2012; Li et al., 2013; Xue et al., 2017). On the eastern QTP L. virgaurea is a poisonous and invasive grassland weed that is becoming increasingly common. It is also found in Bhutan and Nepal (Liu, 1989). As a strongly colonizing perennial herb bearing allelopathic toxins (Wang et al., 2018), L. virgaurea is an excellent indicator species of grassland degradation on the QTP (Wang et al., 2008). Its wide distribution has led to a reduction in grassland productivity, seriously threatening forage quality and sustainable development of animal husbandry in the region (Shi et al., 2018; Wang et al., 2018). While its chemical composition (Tori et al., 2006), seed germination and impact on soil biochemical factors (Shi et al., 2011; Shi et al., 2018) have been studied, its leaf ecological stoichiometry remains undocumented.

Carbon $(\mathrm{C})$, nitrogen $(\mathrm{N})$ and phosphorus $(\mathrm{P})$ are plants' basic building blocks (Elser et al., 2000). Commonly known as ecological stoichiometry, the balance of multiple elements (mainly $\mathrm{C}, \mathrm{N}$ and $\mathrm{P}$ ) in plant tissues and its interaction with the ecosystem (Reich et al., 2006; Bradshaw et al., 2012; Jiang et al., 2019), provides a new theoretical approach to study the coupling of elements in the ecosystem, its structural and functional stability, and the means to its potential restoration (Güsewell and Bollens, 2003; Güsewell, 2010). Among the elements of interest, $\mathrm{C}$ is the most important in terms of dry matter and is the substrate and energy source essential to several physiological processes (Yang and Wang, 2011). In contrast, $\mathrm{N}$ and $\mathrm{P}$, as key substrates in various biological processes operating in plants, are plants' main growth-limiting elements ( $\mathrm{Li}$ et al., 2017; Müller et al., 2017).

In 1986, Reiners (1986) first explicitly incorporated stoichiometry as a complementary theory of ecosystem research by organically combining ecology with stoichiometry. Many studies on plants' ecological stoichiometry have followed. Plant ecological stoichiometry distribution patterns and their driving factors have been investigated at the regional scale (Sardans et al., 2011; Cao et al., 2020; Liu et al., 2021; Niu et al., 2021), and between different vegetation types ( $\mathrm{He}$ et al., 2019; Qin et al., 2021). Differences in ecological stoichiometry have been noted in different plant organs (Zhang et al., 2017; Hu et al., 2018; Zhang et al., 2021), and under the influence of different disturbances: e.g., shifts in soil moisture or nutrient content, invasive plant species, land degradation, and the implementation of various ecological recovery measures ( $\mathrm{Hu}$ et al., 2018; Ouyang and Norton, 2019; Jing et al., 2020).

As plants' main photosynthetic organ, the leaf serves an important role in energy exchange and material transfer between the environment and plants (Sun et al., 2017b). Consequently, a leaf's stoichiometric features are closely related to the structure and function of the terrestrial ecosystem harboring the plant (Güsewell, 2010). The study of leaf ecological stoichiometry has become an effective method for determining plant growth rates, quantifying nutrient utilization efficiency and estimating the availability of soil nutrients for plant growth (Mcgroddy et al., 2004; Qin et al., 2021). Leaf ecological stoichiometry at the community or plant family level in terrestrial ecosystems has been intensively studied (Cao et al., 2020). On the northeast QTP, leaf ecological stoichiometry along an elevation gradient (Qin et al., 2021) has been explored at the community level, and for given individual plant species - e.g., $O$. ochrocephala (Cao et al., 2020), S. chamaejasme (Su et al., 2021), P. bifurca (Xu et al., 2018), Leontopodium leontopodioides (Xu et al., 2019). These studies have indicated that each species has its own specific leaf stoichiometry even when it faces the same environmental conditions.

The study of grassland degradation indicator species' ecological chemometrics and their driving factors can further elucidate grassland degradation mechanisms and inform the formulation of grassland management measures ( $\mathrm{Li}$ et al., 2018). In the present case, investigation of leaf ecological stoichiometry of $L$. virgaurea at different elevations in the northeast QTP sought to elucidate the adaptive strategies of $L$. virgaurea to environmental changes through the regulation of its leaf ecological stoichiometry. Based on previous studies (e.g., Cao et al., 2020; Qin et al., 2021), our hypothesis was that leaf ecological stoichiometry of $L$. virgaurea would change with changes in temperature, precipitation, and soil physical and chemical properties linked to changes in elevation within the study area.

\section{MATERIALS AND METHODS}

\section{The Study Area}

Situated in the northeast QTP (lat. $38^{\circ} 32^{\prime}-38^{\circ} 48^{\prime} \mathrm{N}$, long. $100^{\circ} 03^{\prime}-100^{\circ} 23^{\prime} \mathrm{E}$ ), and ranging in elevation from 2000 to $4,700 \mathrm{~m}$, the study area is subject to a typical continental climate. The region's minimum, maximum, and annual mean temperatures over $1987-2001$ were $-12.5^{\circ} \mathrm{C}, 19.6^{\circ} \mathrm{C}$ and $5.4^{\circ} \mathrm{C}$, respectively (Yang et al., 2004). Over the same period, precipitation ranged between 300 and $500 \mathrm{~mm} \mathrm{y}^{-1}$, while evapotranspiration averaged $1,488 \mathrm{~mm} \mathrm{y}^{-1}$ (Yang et al., 2004). According to China's soil classification system, the main soil types were frigid calcic soils, aeolian soils, red earths, felty soils, paddy soils, castanozems and dark-brown earths, etc. In these mountainous areas, grasslands are predominantly situated on south-, east-, and west-facing slope aspects, while north-facing slopes are dominated by Picea crassifolia Kom. trees. The grassland vegetation 
includes Carex tristachya Thunb., Kobresia bellardii (All.) Degl. ex Loisel, S. chamaejasme, Oxytropis alpina Ten. and $L$. virgaurea.

\section{Experiment Design and Method}

In August 2018, sampling sites were selected at three elevations: $2,600,3,000$, and $3,300 \mathrm{~m}$ amsl. At each site, three $10 \times 10 \mathrm{~m}^{2}$ plots were randomly laid out, with $10 \mathrm{~m}$ between adjacent plots. Leaves of $L$. virgaurea were collected from five healthy plants with a similar degree of development within each plot. The leaves were taken from the middle of the plant, and stored in an envelope. After the leaves were sampled, three $1 \times 1 \mathrm{~m}^{2}$ quadrats were set up along the diagonal (two ends and one midpoint) of each plot. At the center and four corners of each quadrat, soil samples were collected at three different depths $(0-0.10 \mathrm{~m}, 0.10-0.20 \mathrm{~m}$, and $0.20-0.40 \mathrm{~m}$ ), using a $35 \mathrm{~mm}$ diameter drill. For each soil layer and each quadrat, the soil samples collected from the center and four corners were combined into a composite sample; this was then divided into two portions: one used to estimate soil moisture content, the other for the determination of soil physical and chemical properties.

After the fresh soil samples were weighed $\left(\mathrm{W}_{1}\right)$, they were dried in an oven at $105^{\circ} \mathrm{C}$ to a constant weight, $\mathrm{W}_{2}(\mathrm{~g})$. Gravimetric soil water content (SWC) was calculated as (Qin et al., 2019):

$$
\mathrm{SWC}=100 \cdot \frac{\mathrm{W}_{1}-\mathrm{W}_{2}}{\mathrm{~W}_{2}}
$$

Leaves were dried $\left(65^{\circ} \mathrm{C}, 48 \mathrm{~h}\right)$, ground, and their elemental (C, N, and P) concentrations determined. Samples for measuring soil physical and chemical properties were dried at room temperature in a darkened room. After impurities were removed, the soil was ground via a $2 \mathrm{~mm}$ mesh sieve, and the $\mathrm{pH}$ and soil nutrient levels were determined. A slurry of $1.0 \mathrm{~g}$ of dry soil and $2.5 \mathrm{ml}$ of distilled water was placed in an Erlenmeyer flask and shaken for $10 \mathrm{~min}$, then solids were allowed to settle $1-3 \mathrm{~h}$. Soil $\mathrm{pH}$ was measured using a glass electrode connected to a pH meter PB-10 (Sartorius, Beijing, China) to measure the decanted supernatant. A volumetric potassium dichromate method was used to measure soil organic carbon (SOC) and leaf carbon concentration $\left([\mathrm{C}]_{\text {leaf }}\right)$ (Nelson and Sommers, 1982). Following selenium-catalyzed $\mathrm{H}_{2} \mathrm{SO}_{4}-\mathrm{K}_{2} \mathrm{SO}_{4}-\mathrm{CuSO}_{4}$ digestion of leaf or soil samples, soil total nitrogen $(\mathrm{STN})$ and leaf nitrogen concentration $\left([\mathrm{N}]_{\text {leaf }}\right)$ were determined (Bao, 2000). Using $\mathrm{H}_{2} \mathrm{O}_{2}-\mathrm{H}_{2} \mathrm{SO}_{4}$ digestion to extract P from leaf and soil material, soil total phosphorus (STP) and leaf phosphorus concentration $\left([\mathrm{P}]_{\text {leaf }}\right)$ were determined colorimetrically (Olsen, 1954). Temperature and precipitation at the sampling sites were calculated according to temporal and spatial simulation empirical formulas (Eqs. (2) and (3) (Zhao et al., 2005; 2006):

$$
\begin{aligned}
\text { Temperature } & =20.96-5.49 \times 10^{-3} \mathrm{~W}-0.17 \mathrm{Q}+8.9 \times 10^{-3} Z, R^{2} \\
& =0.98
\end{aligned}
$$

$$
\begin{aligned}
\text { Precipitation } & =1.68 \times 10^{3}+0.12 W+12.41 Q-75.26 Z, R^{2} \\
& =0.92
\end{aligned}
$$

where $W$ stands for elevation, $Q$ for latitude, $Z$ for longitude, and $R^{2}$ is the regression coefficient.

Differences in and fixed effects of elevation and random effect by plot were analysed using linear mixed model (details in section below) on soil physical and chemical properties, and on temperature and precipitation, among the sampling sites at different elevations, which are presented in Table $\mathbf{1}$.

\section{Data Analysis}

For checking samples independence, linear mixed model (LMM) was used to determine the magnitude of elevation (fixed effects) and plot (random effects) on soil physical and chemical properties and leaf ecological stoichiometry of $L$. virgaurea (Liu et al., 2018). Differences in leaf ecological stoichiometry and soil properties of $\mathrm{L}$. virgaurea at different elevations were examined using the $t$-test. Redundancy Analysis (RDA) was used to test the relationship between temperature, precipitation and soil physical and chemical properties and leaf ecological stoichiometry of L. virgaurea across elevations. After RDA analysis, the structural equation model (SEM) was used to further explore the indirect or direct effects of SWC, temperature, and precipitation on $[\mathrm{C}]_{\text {leaf }},[\mathrm{N}]_{\text {leaf }}$ and $[\mathrm{P}]_{\text {leaf }}$ (Wang et al., 2016). An insignificant $\chi^{2}$ test $(p>0.05)$, goodness fit index (GFI) $(>0.90)$ and root mean square residual (RMR) $(<0.05)$ were used to determine the adequacy of the SEM model fit (Hooper et al., 2008). Descriptive statistics and $t$-test were conducted in SPSS 22.0 (SPSS Inc. Chicago, United States). The LMM and RDA were performed by RStudio 4.0.1, while SEM was done using Amos 22.0 (Smallwaters Corporation, Chicago, IL, United States). The chosen significance level was $p \leq 0.05$.

\section{RESULTS}

\section{The Independence of Leaf Samples Testing}

The LMM showed that the effect of plot (random effects) on leaf ecological stoichiometry of $L$. virgaurea was not significant, while except for $[\mathrm{P}]_{\text {leaf }}$ and $[\mathrm{N}]_{\text {leaf: }}:[\mathrm{P}]_{\text {leaf }}$, elevation (fixed effects) exerted a significant effect on leaf ecological stoichiometry of L. virgaurea (Table 2).

\section{Variation in Leaf Ecological Stoichiometry of $L$. virgaurea at Different Elevations}

From $2,600 \mathrm{~m}$ to $3,000 \mathrm{~m}-3,300 \mathrm{~m},[\mathrm{C}]_{\text {leaf }}$, and $[\mathrm{C}]_{\text {leaf: }}[\mathrm{N}]_{\text {leaf }}$ first decreased and then increased, both showing a maximum value at $2,600 \mathrm{~m}$ (446.22 $\mathrm{g} \cdot \mathrm{kg}^{-1}$ and 21.36, respectively) (Figures 1, $2 A, D)$. The $[\mathrm{N}]_{\text {leaf }}$ increased significantly with elevation, but $[\mathrm{P}]_{\text {leaf }}$ increased more gradually, only the $2,600 \mathrm{~m}$ and $3,300 \mathrm{~m}$ elevations showing a significant difference (Figures 2B,C). Ranging from 178.71 to $617.55,[\mathrm{C}]_{\text {leaf }}[\mathrm{P}]_{\text {leaf }}$ at $2,600 \mathrm{~m}$ was 
TABLE 1 | Soil properties, temperature and precipitation across the elevation gradient within the study area.

\begin{tabular}{|c|c|c|c|c|c|c|c|}
\hline \multirow{2}{*}{$\begin{array}{l}\text { Environmental } \\
\text { factors }\end{array}$} & \multicolumn{3}{|c|}{ Elevation } & \multicolumn{2}{|c|}{ Elevation (fixed effects) } & \multicolumn{2}{|c|}{ Plot (random effects) } \\
\hline & $2600 \mathrm{~m}$ & $3000 \mathrm{~m}$ & $3300 \mathrm{~m}$ & $\mathbf{R}^{2} \mathbf{m}$ & $p$-value & $\mathbf{R}^{2} \mathbf{c}$ & $p$-value \\
\hline SWC (\%) & $6.61 \pm 1.62 b$ & $5.64 \pm 0.85 b$ & $21.09 \pm 6.36 \mathrm{a}$ & 0.7546 & 0.0024 & 0.8860 & 0.0144 \\
\hline $\mathrm{pH}$ & $8.31 \pm 0.09 b$ & $8.45 \pm 0.08 \mathrm{a}$ & $8.01 \pm 0.12 c$ & 0.7926 & 0.0002 & 0.7926 & 0.9999 \\
\hline $\mathrm{SOC}\left(\mathrm{g} \cdot \mathrm{kg}^{-1}\right)$ & $16.01 \pm 2.84 b$ & $13.70 \pm 2.07 b$ & $39.44 \pm 10.19 a$ & 0.7696 & 0.0010 & 0.8415 & 0.1710 \\
\hline STN $\left(\mathrm{g} \cdot \mathrm{kg}^{-1}\right)$ & $1.06 \pm 0.19 c$ & $1.50 \pm 0.27 b$ & $3.81 \pm 0.69 a$ & 0.8793 & 0.0001 & 0.9044 & 0.3619 \\
\hline STP $\left(g \cdot \mathrm{kg}^{-1}\right)$ & $0.56 \pm 0.10 a$ & $0.34 \pm 0.10 \mathrm{~b}$ & $0.55 \pm 0.11 \mathrm{a}$ & 0.4803 & 0.0228 & 0.6322 & 0.2002 \\
\hline SOC: STN & $15.18 \pm 2.10 \mathrm{a}$ & $9.20 \pm 1.12 b$ & $10.23 \pm 1.23 b$ & 0.7372 & 0.0011 & 0.7915 & 0.3653 \\
\hline SOC: STP & $30.20 \pm 10.57 \mathrm{c}$ & $44.34 \pm 16.59 b$ & $71.98 \pm 11.03 a$ & 0.6424 & 0.0024 & 0.6794 & 0.6480 \\
\hline STN: STP & $2.01 \pm 0.75 c$ & $4.77 \pm 1.53 b$ & $7.06 \pm 1.01 \mathrm{a}$ & 0.7729 & 0.0003 & 0.7729 & 0.9999 \\
\hline LONG & $100^{\circ} 17^{\prime} 18^{\prime \prime} \mathrm{E}$ & $100^{\circ} 14^{\prime} 26^{\prime \prime} \mathrm{E}$ & $100^{\circ} 22^{\prime} 35^{\prime \prime} \mathrm{E}$ & - & - & - & - \\
\hline LAT & $38^{\circ} 34^{\prime} 2.8^{\prime \prime} \mathrm{N}$ & $38^{\circ} 33^{\prime} 22^{\prime \prime} \mathrm{N}$ & $38^{\circ} 38^{\prime} 15^{\prime \prime} \mathrm{N}$ & - & - & - & - \\
\hline $\mathrm{T}\left({ }^{\circ} \mathrm{C}\right)$ & 1.17 & -1.02 & -2.13 & - & - & - & - \\
\hline $\mathrm{P}\left(\mathrm{mm} \cdot \mathrm{y}^{-1}\right)$ & 331.36 & 379.22 & 398.58 & - & - & - & - \\
\hline
\end{tabular}

Row-wise non-matching letters indicate a significant difference among elevations at $\mathrm{p} \leq 0.05$ level. $\mathrm{pH}$ : soil pH; SWC: soil water content; SOC: soil organic carbon concentration; STN: soil total nitrogen concentration; STP: soil total phosphorus concentration; LONG: Iongitude; LAT: latitude; $R^{2} m$ : the degree of variation of the variable interpreted from the fixed effects; $R^{2} c$ : the degree of variation of the variable interpreted combination from the fixed and random effects; T: temperature; P: precipitation; "-": Test was not done.

TABLE 2 | Linear mixed model results of the effects of elevation and plot on leaf ecological stoichiometry of $L$. virgaurea.

Variable

\begin{tabular}{lccccccc} 
& \multicolumn{9}{c}{} & & & & & \multicolumn{2}{c}{ effects) } \\
& $\mathbf{F}$ & $\mathbf{d f}$ & $\mathbf{R}^{\mathbf{2}} \mathbf{m}$ & p-value & & $\mathbf{R}^{\mathbf{2}} \mathbf{c}$ & p-value \\
\hline$[\mathrm{C}]_{\text {leaf }}\left(\mathrm{g} \cdot \mathrm{kg}^{-1}\right)$ & 198.12 & 2 & 0.9384 & $<0.0001$ & & 0.9384 & 1.0000 \\
{$[\mathrm{~N}]_{\text {leaf }}\left(\mathrm{g} \cdot \mathrm{kg}^{-1}\right)$} & 197.09 & 2 & 0.9663 & $<0.0001$ & & 0.9814 & 0.0460 \\
{$[\mathrm{P}]_{\text {leaf }}\left(\mathrm{g} \cdot \mathrm{kg}^{-1}\right)$} & 2.84 & 2 & 0.1790 & 0.1359 & & 0.1790 & 0.9999 \\
{$[\mathrm{C}]_{\text {leaf: }}[\mathrm{N}]_{\text {leaf }}$} & 319.24 & 2 & 0.9609 & $<0.0001$ & & 0.9609 & 1.0000 \\
{$[\mathrm{C}]_{\text {leaf: }}[\mathrm{P}]_{\text {leaf }}$} & 6.39 & 2 & 0.3295 & 0.0326 & & 0.3295 & 0.9999 \\
{$[\mathrm{~N}]_{\text {leaf: }}[\mathrm{P}]_{\text {leaf }}$} & 0.91 & 2 & 0.0656 & 0.4506 & & 0.0656 & 0.9999
\end{tabular}

pH: soil pH; SWC: soil water content; SOC: soil organic carbon concentration; STN: soil total nitrogen concentration; STP: soil total phosphorus concentration; [C] lear: leaf carbon concentration; $[N]_{\text {leaf: }}$ leaf nitrogen concentration; $[P]_{\text {leaf }}$ : leaf phosphorus concentration. $R^{2} m$ : the degree of variation of the variable interpreted from the fixed effects; $R^{2}$ : the degree of variation of the variable interpreted combination from the fixed and random effects.

significantly greater than at other elevations, but no difference existed between the two higher elevations (Figure 2E); meanwhile $[\mathrm{N}]_{\text {leaf }}:[\mathrm{P}]_{\text {leaf }}$ showed no significant change across elevations (Figure 2F).

\section{Influence of Environmental Factors on the Ecological Stoichiometry of $L$. virgaurea}

The RDA showed the first and second axes to collectively explain $59.11 \%$ of the total variation in L. virgaurea leaf ecological stoichiometry, with the first and second axes explaining 35.34 and $23.77 \%$ of the variation, respectively (Figure 3). Among the environmental factors, temperature, precipitation and SWC had the greatest effect on $L$. virgaurea leaf ecological stoichiometry (Table 3).

The results of the SEM showed that environmental factors can explain about 80,94 and $21 \%$ of the variation of $[\mathrm{C}]_{\text {leaf }}$, $[\mathrm{N}]_{\text {leaf }}$ and $[\mathrm{P}]_{\text {leaf }}$, respectively (Figure 4). The SWC indirectly affected $[\mathrm{C}]_{\text {leaf }}$ through three paths: SOC: STN path, SOC-STP path, and SOC-pH path (Figure 4A). Temperature directly affected $[\mathrm{N}]_{\text {leaf }}$, but SWC indirectly affected it through one path: SOC-pH (Figure 4B). Precipitation indirectly affected $[\mathrm{P}]_{\text {leaf }}$ through three paths: STP-STN: STP path, SWC-STN: STP path and SWC-STPSTN: STP path, while temperature indirectly affected it through one path: STN: STP path (Figure 4C).

\section{DISCUSSION}

\section{Dominant Factors Influencing the Ecological Stoichiometry of $L$. virgaurea Across Elevations}

The results from the LMM showed that except for $[\mathrm{P}]_{\text {leaf }}$ and $[\mathrm{N}]_{\text {leaf: }}[\mathrm{P}]_{\text {leaf }}$, leaf ecological stoichiometry of $L$. virgaurea was mainly determined by elevation, and not plot, suggesting the independence of samples (Liu et al., 2018). Change in environment as elevation increased from 2,600 to $3,300 \mathrm{~m}$ altered L. virgaurea leaf ecological stoichiometry to some extent, with the exception of $[\mathrm{N}]_{\text {leaf }}[\mathrm{P}]_{\text {leaf }}$ (Figure 2), as was found in other studies (Liu et al., 2021; Su et al., 2021). However, sometimes, leaf ecological stoichiometry is related to the plant's inherited characteristics. For example, the leaves of long-lived and slow-growing plants often have a lower element concentration than ones from plants with contrasting features (Sun et al., 2017a).

In the present study, elevation mainly affected leaf ecological stoichiometry of $L$. virgaurea by influencing temperature, precipitation and SWC (Table 3), which is similar to the factors of influence reported by $\mathrm{Su}$ et al. (2021). This largely supported our hypothesis that leaf ecological stoichiometry of $L$. virgaurea would change with temperature and precipitation when elevation changes. Except for SWC, other soil physical and chemical properties had little direct effect on leaf ecological stoichiometry of L. virgaurea, only weakly supporting our 


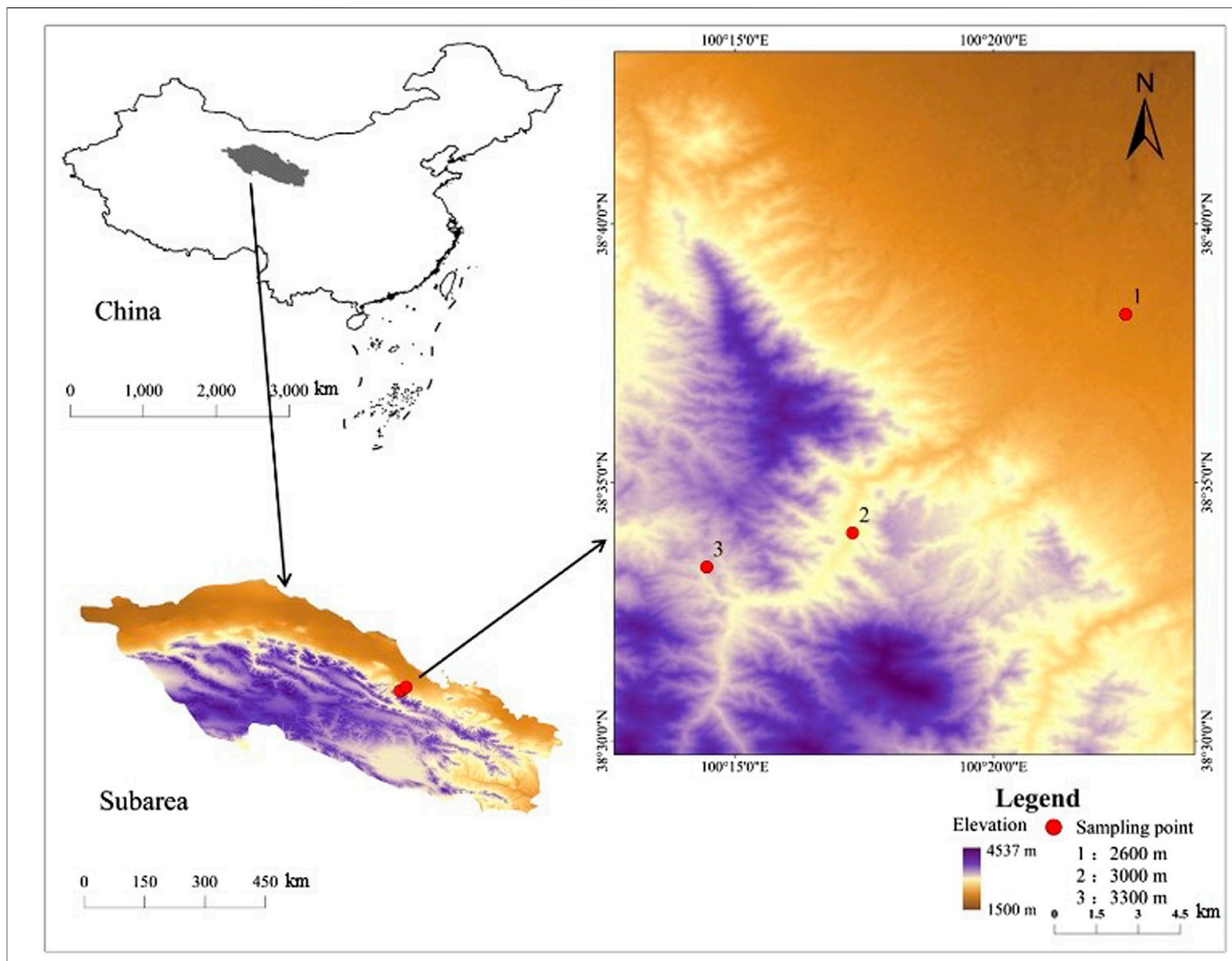

FIGURE 1 | Location of the sampling sites at 2,600, 3,000 and 3,300 m within the study area.

hypothesis that leaf ecological stoichiometry of $L$. virgaurea would change with soil physical and chemical properties when elevation changes. However, Liu et al. (2021) found that, under changes in elevation, the effects of temperature and precipitation on the leaf ecological stoichiometry of Potentilla fruticosa were not as great as $\mathrm{pH}, \mathrm{STP}$ and SOC. This suggests that although elevation affects leaf ecological stoichiometry of different species, the specific influencing factors can be different, as the niche for each species differs (Silvertown, 2004). It is, therefore, that in understanding the adaptation strategies of a given species with changes of elevation, its leaf ecological stoichiometry must be independently studied.

\section{Mechanisms for the Dominant Factors Affecting $[\mathrm{C}]_{\text {leaf }}$ Across Elevations}

In general, in an environment with lower soil water content, leaves need to maintain a greater $[\mathrm{C}]_{\text {leaf }}$ and specific leaf weight, as they must reduce photosynthetic and growth rates in order to reduce water consumption and improve their defenses against an adverse environment (Poorter and Bongers, 2006). Most studies have found that soil water content is negatively correlated with $[\mathrm{C}]_{\text {leaf }}$ (Hu et al., 2018; Liu et al., 2020). In the present study, among these above-mentioned dominant factors, only SWC indirectly affected $[\mathrm{C}]_{\text {leaf }}$ of $L$. virgaurea through three paths, namely SOC: STN path, SOC-STP path, and SOC-pH path (Figure 4A). The first path can be explained: as an important physical property of soil, soil moisture often has an important impact on other physical and chemical properties (Lin et al., 2021). For instance, with the increase of SWC, soil oxygen concentration and microbial activity will decrease (Borken and Matzner, 2009), which, in turn, will decrease the mineralization rate, as reflected by SOC: STN (Swift et al., 1979; Sanaullah et al., 2012). The other two paths can also be explained: an increase in SWC can lead to the cracking and dispersal of soil aggregates, which in turn dissolve and release forms of organic matter that are difficult for microorganisms to use, thus increasing SOC (Liu et al., 2014; Lin et al., 2021). With a change in SOC, pH and STP 

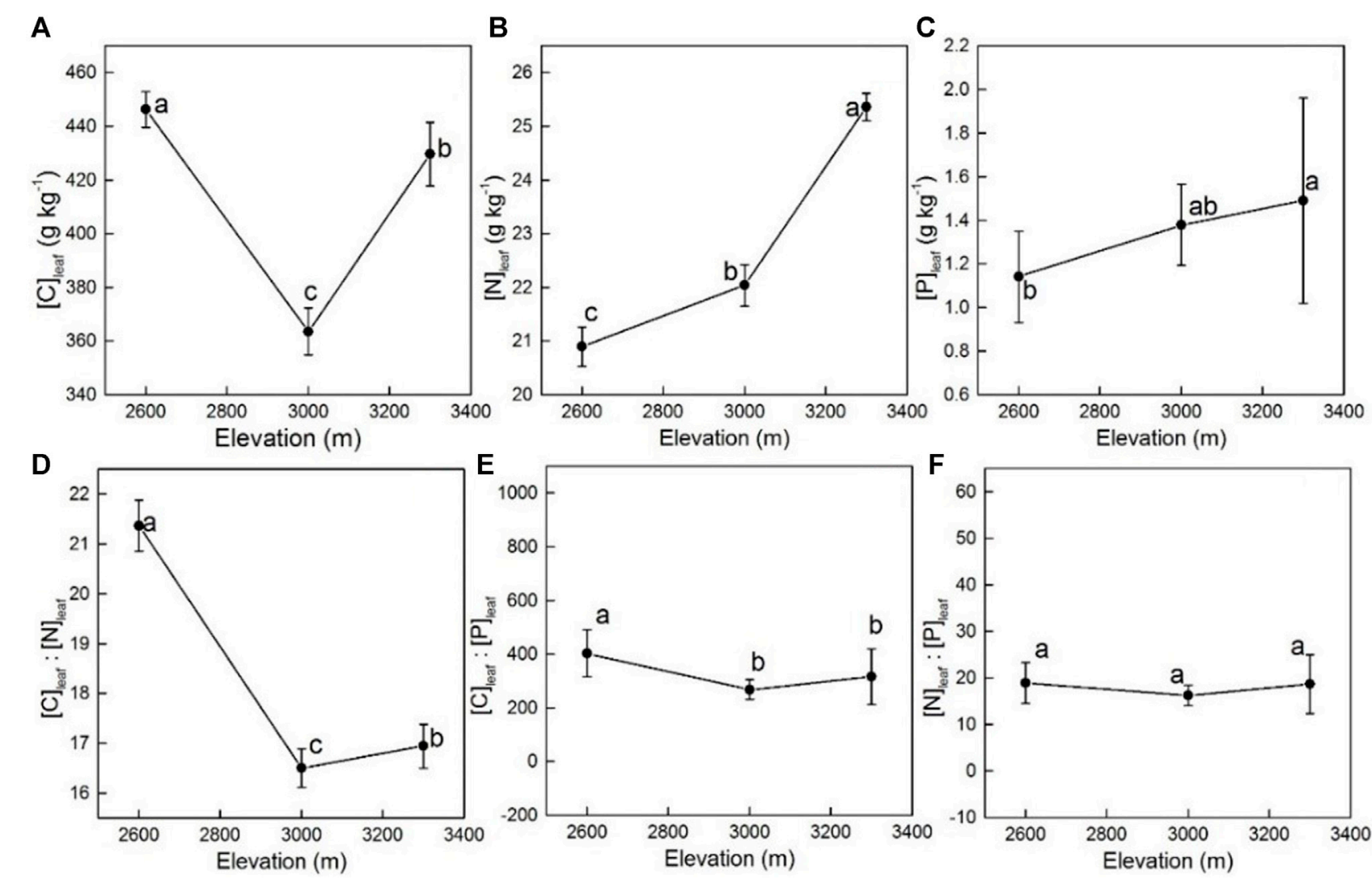

FIGURE 2 |L. virgaurea leaf carbon concentration (A), leaf nitrogen concentration (B), and leaf phosphorus concentration (C) and $[C]_{\text {leaf: }}[\mathrm{N}]_{\text {leaf }}$ (D), $[\mathrm{C}]_{\text {leaf: }}[\mathrm{P}]_{\text {leaf }}$

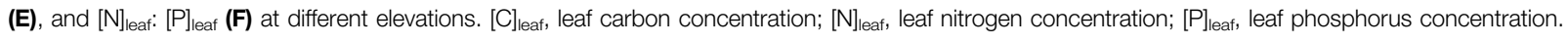

will also be affected (Figure 4A). Soil acidity has been found to increase with increasing SOC due to the release of $\mathrm{H}^{+}$(Liu et al., 2019a). The relationship between SOC and STP is consistent with the findings of Cao et al. (2013) who found that increased soil organic matter can increase the STP, but the reason behind this requires further study.

With SOC: STN, STP and pH, as influenced by SWC, these exerted direct effects on $[\mathrm{C}]_{\text {leaf }}$ of L. virgaurea. The average SOC: STN (11.54) was less than 25 in the study area, suggesting that the effective $\mathrm{N}$ produced by mineralization of organic matter could be used for plant growth (Haynes, 1986; Prescott et al., 2000; Li et al., 2019). With plant growth and photosynthesis enhanced (Tjoelker et al., 2010), [C] $]_{\text {leaf }}$ would accumulate (Figure 4A). The STP is largely dependent on the soil parent body (Liu et al., 2005), and the P in the leaf is transported from the plant roots which take up P from the host soil (Parton et al., 1988). As the leaf's P increased with STP (Figure 4A), so $[\mathrm{C}]_{\text {leaf }}$ increased, because $\mathrm{P}$ also participates in photosynthesis. The effect of $\mathrm{pH}$ on $[\mathrm{C}]_{\text {leaf }}$ is opposite of that of SOC: STN and STP on $[\mathrm{C}]_{\text {leaf }}$ (Figure 4A). It was found that higher $\mathrm{pH}$ values were often associated with a higher salt content (Kissel et al., 2009). The soil $\mathrm{pH}$ at different elevations in the study area was above 8 (Table 1), indicating a high salt content that would likely reduce stomatal conductivity (He et al., 2016) and water level in the leaf (Flowers and Colmer, 2008), thereby inhibiting leaf photosynthesis and reducing $[\mathrm{C}]_{\text {leaf }}$.

\section{Mechanisms for the Dominant Factors Affecting [N] $]_{\text {leaf }}$ Across Elevations}

Temperature regulates the function of plant cells by affecting a series of physical and chemical reactions (e.g., enzyme activity and membrane systems) that affect leaf ecological stoichiometry (Hall et al., 2010; Liu et al., 2019b). Temperature directly affected $[\mathrm{N}]_{\text {leaf }}$ of $L$. virgaurea, while SWC indirectly affected it (Figure 4B).

The relationship between temperature and $[\mathrm{N}]_{\text {leaf }}$ was consistent with that in most studies (Han et al., 2005; Chen et al., 2013) and the temperature-plant physiology hypothesis (Reich et al., 2004). This hypothesis posits that the decrease of temperature would result in a greater leaf nutrient concentration to compensate for the decline in metabolic rate, thereby improving plant tissues' adaptation to temperature and nutrition utilization. It was reflected by a significant increase in $[\mathrm{N}]_{\text {leaf }}$ with the increase in elevation (Figure $2 \mathbf{B}$ ). With $\mathrm{pH}$ influenced by SOC and SWC, it exerted a directly effect on $[\mathrm{N}]_{\text {leaf }}$ of L. virgaurea (Figure 4B). The relationship between $\mathrm{pH}$ and $[\mathrm{N}]_{\text {leaf }}$ was consistent with the results of Liu et al. (2021). As soil alkalinity decreased and acidity increased, the activity of some 


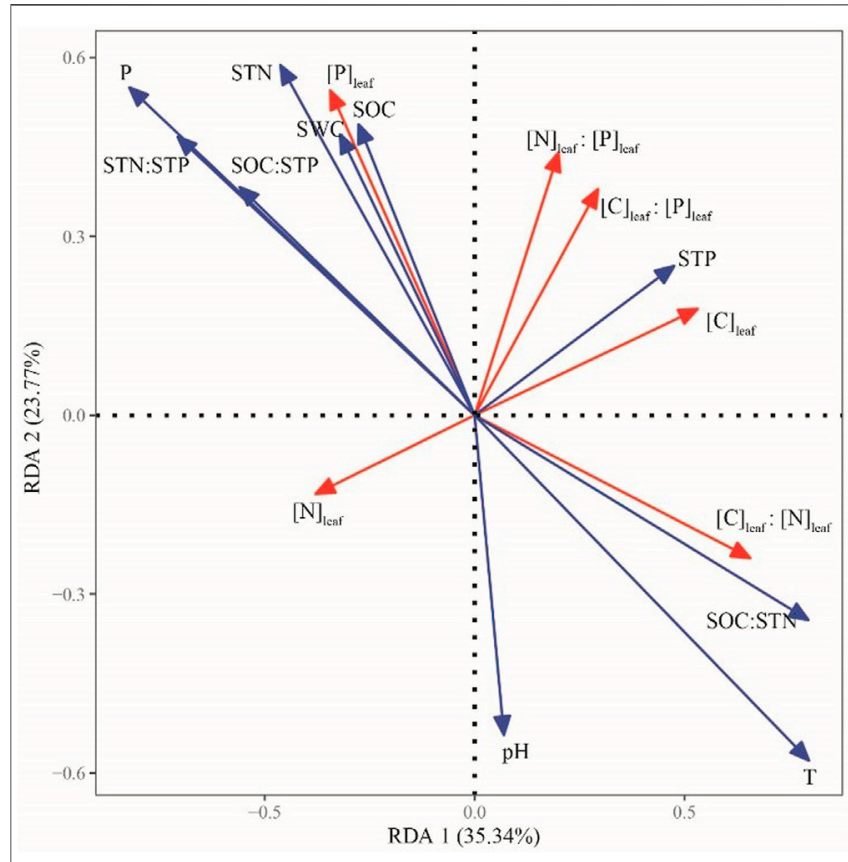

FIGURE 3 | Redundancy analysis (RDA) ordination for the leaf stoichiometric traits of $L$. virgaurea and environmental characteristics. $\mathrm{pH}$, soil $\mathrm{pH}$; SWC, soil water content; SOC, soil organic carbon concentration; STN, soil total nitrogen concentration; STP, soil total phosphorus concentration; $[\mathrm{C}]_{\text {leaf }}$, leaf carbon concentration; $[\mathrm{N}]_{\text {leaf, leaf nitrogen }}$ concentration; $[\mathrm{P}]_{\text {leaf }}$, leaf phosphorus concentration; $\mathrm{T}$, temperature; $\mathrm{P}$, precipitation.

metals in the soil increased, forming insoluble substances (e.g., Fe-phosphorus, Al-phosphorus, etc.), leading to a reduction in the availability of soil nutrients and making it difficult for plants to take up nutrients from the soil (Buchkowski et al., 2015). At this point, the plants may promote their own reabsorption of nutrients in order to maintain the nutrients for growth, resulting in the increase of $[\mathrm{N}]_{\text {leaf }}$ (Aerts, 1996).

\section{Mechanisms for the Dominant Factors Affecting $[\mathrm{P}]_{\text {leaf }}$ Across Elevations}

The precipitation indirectly affected $[\mathrm{P}]_{\text {leaf }}$ of $L$. virgaurea through three paths, namely STP-STN: STP path, SWC-STN: STP path and SWC-STP- STN: STP (Figure 4C). These paths can be explained: precipitation can influence soil nutrient concentrations and uptake effectiveness, along with soil water content (Liu et al., 2019a). For instance, with an increase in precipitation, the $\mathrm{P}$ leaching process is accelerated, resulting in a decreased STP concentration (Jiang et al., 2019). Increased precipitation can also lead to a high SWC, and reduce microbial activity (Borken and Matzner, 2009; Jiang et al., 2019). As microbial activity decreased, the conversion and use of STP by microbes would be reduced or stopped, resulting in increasing STP and consequently reducing the STN: STP ratio (Taylor et al., 1989). Temperature only indirectly affected $[\mathrm{P}]_{\text {leaf }}$ of $L$. virgaurea through one path (Figure 4C). The reason for this is that low temperature can reduce microbial activity (Borken and
Matzner, 2009; Jiang et al., 2019) and increase STN: STP as mentioned above.

With STN: STP influenced by temperature, precipitation and SWC, it exerted a direct effect on $[\mathrm{P}]_{\text {leaf }}$ of $L$. virgaurea. Generally, STN: STP affects plant productivity and composition, as well as the composition and biological activity of soil microorganisms (Mulder and Elser, 2009; Zhao et al., 2018; Liu et al., 2010). With a change in the effective soil $\mathrm{P}$ concentrations that can be absorbed and utilized by plants due to biological activity influenced by environmental changes (Ouyang and Norton, 2019), [P $]_{\text {leaf }}$ will be affected. However, SEM showed that environmental factors can explain only about $21 \%$ of the variation of $[\mathrm{P}]_{\text {leaf }}$ in the study area (Figure 4), suggesting that other factors such as species' own genetic characteristics may be more important for determining $[\mathrm{P}]_{\text {leaf }}$ of L. virgaurea; further study is needed.

\section{Implications for Grassland Management}

Since the leaf ecological stoichiometry of L. virgaurea was mainly affected by climate (temperature and precipitation) (Table 3 ), future climate change is expected to have an impact on the growth of $L$. virgaurea in the study area. The $[\mathrm{C}]_{\text {leaf: }}[\mathrm{N}]_{\text {leaf }}$ and $[\mathrm{C}]_{\text {leaf: }}$ : $[\mathrm{P}]_{\text {leaf }}$ not only reflect plants' $\mathrm{N}$ and $\mathrm{P}$ utilization efficiency (Reich et al., 2006; Sun et al., 2017a), but is also indicative of the rate of plant growth (Jiang and Song, 2010) - with lower $[\mathrm{C}]_{\text {leaf: }}[\mathrm{N}]_{\text {leaf }}$ and $[\mathrm{C}]_{\text {leaf: }}[\mathrm{P}]_{\text {leaf }}$ values, a faster growth rate is achieved (Jiang and Song, 2010; Yan et al., 2015). The temperature and precipitation will both increase across the QTP and thus at the study site. The increase in temperature in high elevation areas will be more significant than at lower elevations. The magnitude of change in precipitation is low in comparison with that of temperature (Liu et al., 2009; Hu et al., 2015; Wang et al., 2019). Based on this, we can infer that with future temperature increases, leaf nutrient concentration compensating metabolic rates will decline in high elevation areas, while the catabolic reaction processes of the soilmicrobe-mediated soil nitrogen cycle will increase, as will nitrogen mineralization (Dai et al., 2020). As a result, more nutrients could be assimilated and allocated to vegetative

TABLE 3 | Level of explanatory capacity and significance of environmental factors in the variation of $L$. virgaurea leaf ecological stoichiometry at different elevations.

\begin{tabular}{lccc} 
Environmental factors & Explains (\%) & $\mathbf{F}$ & $\mathbf{P}$ \\
\hline SWC (\%) & 15.6 & 11.5 & $\mathbf{0 . 0 0 8}$ \\
pH & 0.3 & 0.2 & 0.750 \\
SOC $\left({\left.\mathrm{g} \cdot \mathrm{kg}^{-1}\right)}^{\mathrm{N}}\right.$ & 1.0 & 0.7 & 0.440 \\
STN $\left(\mathrm{g} \cdot \mathrm{kg}^{-1}\right)$ & 0.2 & 0.1 & 0.870 \\
STP $\left(\mathrm{g}^{-1}\right)$ & $<0.1$ & $<0.1$ & 0.984 \\
SOC: STN & 0.7 & 0.5 & 0.512 \\
SOC: STP & 2.8 & 2.2 & 0.116 \\
STN: STP & 1.3 & 1.0 & 0.330 \\
T $\left({ }^{\circ} \mathrm{C}\right)$ & 21.9 & 11.2 & $\mathbf{0 . 0 0 2}$ \\
P $(\mathrm{mm})$ & 31.3 & 11.4 & $\mathbf{0 . 0 0 2}$
\end{tabular}

pH: soil pH; SWC: soil water content; SOC: soil organic carbon concentration; STN: soil total nitrogen concentration; STP: soil total phosphorus concentration; T: temperature; $P$ : precipitation. Significant values are in bold. 


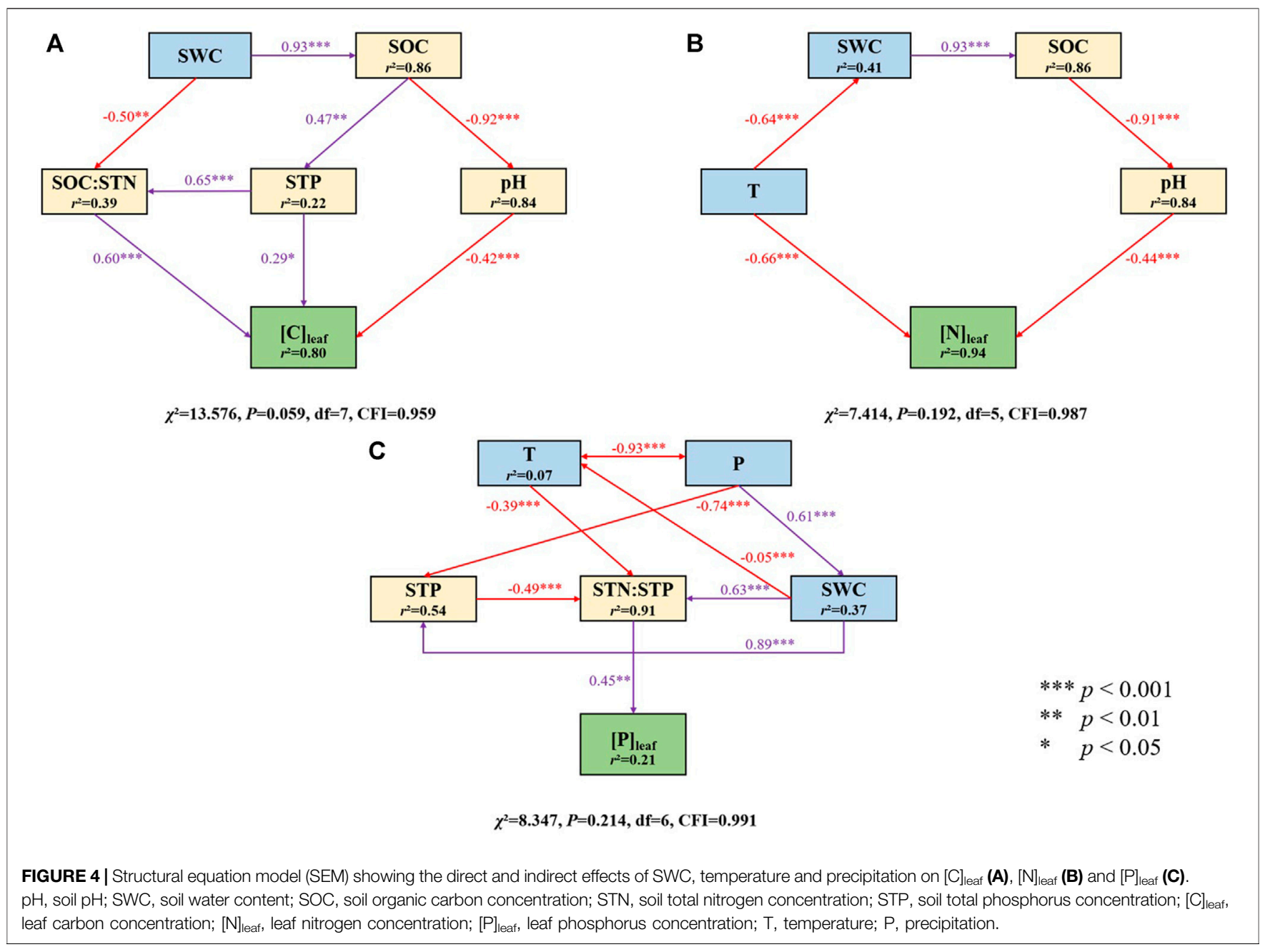

growth, thereby promoting the growth of L. virgaurea. However, as $[\mathrm{N}]_{\text {leaf: }}[\mathrm{P}]_{\text {leaf }}$ of $L$. virgaurea in the study area exceeded $16($ mean $=$ 17.93), L. virgaurea's growth will be restricted by $\mathrm{P}$ (Figure 2F) (Koerselman and Meuleman, 1996; Güsewell, 2010). Nevertheless, determining plant nutrient restriction status based solely on $[\mathrm{N}]_{\text {leaf: }}$ : $[\mathrm{P}]_{\text {leaf }}$ does not tell the full story and environmental factors should be introduced as auxiliary evaluation criteria to further study the impact of nutrient restriction on L. virgaurea (Güsewell, 2010; Batjes, 2014; Niu et al., 2021).

For alpine grazing meadows, previous studies have found that the invasion of L. virgaurea can increase above- and below- biomass, SOC, STN and microbial biomass C and N concentrations in the topsoil (Shi et al., 2011; Shi et al., 2018). This means that the type of grassland degradation caused by L. virgaurea is harmful to plant diversity, especially to grasslands' high quality forage diversity, and eventually to livestock grazing, but it is not harmful to soil $\mathrm{C}$ and other soil nutrients. However, a decline in plant species will affect the stability of grassland ecosystems and decrease other services such as biodiversity protection (Báez et al., 2008; Das et al., 2019). This suggests that there must be a trade-off between soil function and supporting biodiversity threatened by the future spread of L. virgaurea. At present, both are very important for the QTP and all over the world, and thus the spread of $L$. virgaurea must be limited in scope.

\section{CONCLUSION}

Based on field sampling in the northeast QTP and subsequent experimental analysis, L. virgaurea $[\mathrm{N}]_{\text {leaf }}[\mathrm{P}]_{\text {leaf }}$ showed no significant changes with elevation; nevertheless, $[\mathrm{C}]_{\text {leaf }}$, $[\mathrm{N}]_{\text {leaf }},[\mathrm{P}]_{\text {leaf }}$ and $[\mathrm{C}]_{\text {leaf }}:[\mathrm{N}]_{\text {leaf }},[\mathrm{C}]_{\text {leaf }}:[\mathrm{P}]_{\text {leaf }}$ fluctuated with rising elevation, confirming the fact that $L$. virgaurea can adjust its internal physiological characteristics or adopt different resource utilization strategies to adapt to environmental changes. Based on $[\mathrm{N}]_{\text {leaf: }}[\mathrm{P}]_{\text {leaf }}$, we found $L$. virgaurea's growth to be susceptible to $\mathrm{P}$ limitation. However, such putative nutrient limitations must be further studied through a combination of leaf ecological stoichiometry, actual soil nutrient levels and the genuine nutrient requirements of plants in the study area. 
The SWC, temperature and precipitation were the main environmental factors modulating leaf ecological stoichiometry of $L$. virgaurea across elevations. The SWC indirectly affected $[\mathrm{C}]_{\text {leaf }}$ and $[\mathrm{N}]_{\text {leaf }}$, temperature directly affected $[\mathrm{N}]_{\text {leaf }}$, while $[\mathrm{P}]_{\text {leaf }}$ was affected by all their indirect effects. As the contribution of temperature and precipitation to the total variance of leaf ecological stoichiometry was greater than that of SWC, climate change would have a dominant impact on the growth of L. virgaurea. Based on scientific predictions of future climate by researchers and combined with our research results, future climate change would promote the growth of L. virgaurea. Consequently, limiting the spread of $L$. virgaurea may require biological or chemical control in future grassland management.

The environmental factors investigated here only partly explain the changes in leaf ecological stoichiometry of $L$. virgaurea with elevation, which may also be related to other factors, such as vegetation community structure at different elevations, species richness, soil microbial diversity, etc. Moreover, only three elevations were studied here, over limited gradients. Consequently, to further understand the adaptation strategy of $L$. virgaurea in the context of grassland degradation, it is necessary to increase the elevation gradient, and explore the changes in ecological stoichiometry in L. virgaurea at different elevations.

\section{REFERENCES}

Aerts, R. (1996). Nutrient Resorption from Senescing Leaves of Perennials: Are There General Patterns. J. Ecol. 84, 597. doi:10.2307/2261481

Báez, S., Collins, S. L., and Hector, A. (2008). Shrub Invasion Decreases Diversity and Alters Community Stability in Northern Chihuahuan Desert Plant Communities. PLoS One 3, e2332. doi:10.1371/journal.pone.0002332

Bakhshi, J., Javadi, S. A., Tavili, A., and Arzani, H. (2020). Study on the Effects of Different Levels of Grazing and Exclosure on Vegetation and Soil Properties in Semi-arid Rangelands of Iran. Acta Ecologica Sinica 40, 425-431. doi:10.1016/ j.chnaes.2019.07.003

Bao, S. (2000). Soil and Agriculture Chemistry Analysis. Beijing: China Agriculture Press. (in Chinese).

Batjes, N. H. (2014). Batjes, N. H. 1996. Total Carbon and Nitrogen in the Soils of the world.European Journal of Soil Science, 47, 151-163. Reflections by N.H. Batjes. Eur. J. Soil Sci. 65, 2-3. doi:10.1111/ejss.12115

Borken, W., and Matzner, E. (2009). Reappraisal of Drying and Wetting Effects on $\mathrm{C}$ and N Mineralization and Fluxes in Soils. Glob. Change Biol. 15, 808-824. doi:10.1111/j.1365-2486.2008.01681.x

Bradshaw, C., Kautsky, U., and Kumblad, L. (2012). Ecological Stoichiometry and Multi-Element Transfer in a Coastal Ecosystem. Ecosystems 15, 591-603. doi:10.1007/s10021-012-9531-5

Buchkowski, R. W., Schmitz, O. J., and Bradford, M. A. (2015). Microbial Stoichiometry Overrides Biomass as a Regulator of Soil Carbon and Nitrogen Cycling. Ecology 96, 1139-1149. doi:10.1890/14-1327.1

Cao, J., Wang, X., Adamowski, J. F., Biswas, A., Liu, C., Chang, Z., et al. (2020). Response of Leaf Stoichiometry of Oxytropis Ochrocephala to Elevation and Slope Aspect. Catena 194, 104772. doi:10.1016/j.catena.2020.104772

Cao, Y., Wang, X., Lu, Y., Yan, Y., and Fan, J. (2013). Soil Organic Carbon and Nutrients along an Alpine Grassland Transect across Northern Tibet. J. Mt. Sci. 10, 564-573. doi:10.1007/s11629-012-2431-5

Chen, Y., Han, W., Tang, L., Tang, Z., and Fang, J. (2013). Leaf Nitrogen and Phosphorus Concentrations of Woody Plants Differ in Responses to Climate, Soil and Plant Growth Form. Ecography 36, 178-184. doi:10.1111/j.16000587.2011.06833.x

\section{DATA AVAILABILITY STATEMENT}

The original contributions presented in the study are included in the article/supplementary material, further inquiries can be directed to the corresponding author.

\section{AUTHOR CONTRIBUTIONS}

JJC contributed to the conception and planning of the research, and critically reviewed the manuscript, as did JA and AB. XZ and HS performed the experiments and analyzed the data. JBC and HS checked the format and wrote the article. All authors have read and agreed on the final contents of the manuscript. The authors read and approved the final manuscript.

\section{FUNDING}

This study was supported by the Major Program of the Natural Science Foundation of Gansu Province, China, Grant number 18JR4RA002, and the Qilian Mountains Eco-environment Research Center in Gansu Province, Northwest Institute of Eco-environment and Resources, Chinese Academy of Sciences, Grant number QLS202002.

Chuanyan, Z., Zhongren, N., and Guodong, C. (2005). Methods for Modelling of Temporal and Spatial Distribution of Air Temperature at Landscape Scale in the Southern Qilian Mountains, China. Ecol. Model. 189, 209-220. doi:10.1016/ j.ecolmodel.2005.03.016

Dai, Z., Yu, M., Chen, H., Zhao, H., Huang, Y., Su, W., et al. (2020). Elevated Temperature Shifts Soil $\mathrm{N}$ Cycling from Microbial Immobilization to Enhanced Mineralization, Nitrification and Denitrification across Global Terrestrial Ecosystems. Glob. Change Biol. 26, 5267-5276. doi:10.1111/ gcb. 15211

Das, D., Banerjee, S., and John, R. (2019). Predicting the Distribution and Abundance of Invasive Plant Species in a Sub-tropical Woodland-Grassland Ecosystem in Northeastern India. Plant Ecol. 220, 935-950. doi:10.1007/ s11258-019-00964-7

Elser, J. J., Fagan, W. F., Denno, R. F., Dobberfuhl, D. R., Folarin, A., Huberty, A., et al. (2000). Nutritional Constraints in Terrestrial and Freshwater Food Webs. Nature 408, 578-580. doi:10.1038/35046058

Flowers, T. J., and Colmer, T. D. (2008). Salinity Tolerance in Halophytes*. New Phytol. 179, 945-963. doi:10.1111/j.1469-8137.2008.02531.x

Goslee, S. C., Peters, D. P. C., and Beck, K. G. (2001). Modeling Invasive Weeds in Grasslands: The Role of Allelopathy in Acroptilon Repens Invasion. Ecol. Model. 139, 31-45. doi:10.1016/S0304-3800(01)00231-9

Güsewell, S., and Bollens, U. (2003). Composition of Plant Species Mixtures Grown at Various N:P Ratios and Levels of Nutrient Supply. Basic Appl. Ecol. 4, 453-466. doi:10.1078/1439-1791-00174

Güsewell, S. (2004). N : P Ratios in Terrestrial Plants: Variation and Functional Significance. New Phytol. 164, 243-266. doi:10.1111/j.1469-8137.2004.01192.x

Hall, E. K., Singer, G. A., Kainz, M. J., and Lennon, J. T. (2010). Evidence for a Temperature Acclimation Mechanism in Bacteria: An Empirical Test of a Membrane-Mediated Trade-Off. Funct. Ecol. 24, 898-908. doi:10.1111/j.13652435.2010.01707.x

Han, W., Fang, J., Guo, D., and Zhang, Y. (2005). Leaf Nitrogen and Phosphorus Stoichiometry across 753 Terrestrial Plant Species in China. New Phytol. 168, 377-385. doi:10.1111/j.1469-8137.2005.01530.x

Haynes, R. J. (1986). The Decomposition Process: Mineralization, Immobilization, Humus Formation, and Degradation. Mineral Nitrogen in the Plant-soil System. London: Academic Press, 52-126. doi:10.1016/B978-0-12-334910-1.50006-6 
He, M., Luo, Y., Peng, Q., Yang, S., Li, K., and Han, W. (2019). Leaf C:N:P Stoichiometry of 67 Plant Species and its Relations with Climate Factors across the Deserts in Xinjiang, China. Ying Yong Sheng Tai Xue Bao 30, 2171-2180. doi:10.13287/j.1001-9332.201907.025 (in Chinese).

He, Y., Chen, Y., Yu, C. L., Lu, K. X., Jiang, Q. S., Fu, J. L., et al. (2016). Photosynthesis and Yield Traits in Different Soybean Lines in Response to Salt Stress. Photosynt. 54, 630-635. doi:10.1007/s11099-016-0217-7

Hooper, D., Coughlan, J., and Mullen, M. R. (2008). Structural Equation Modelling: Guidelines for Determining Model Fit. Electron. J. Business Res. Methods 6, 141-146. doi:10.3109/03005364000000039

Hu, M., Peñuelas, J., Sardans, J., Sun, Z., Wilson, B. J., Huang, J., et al. (2018). Stoichiometry Patterns of Plant Organ N and P in Coastal Herbaceous Wetlands along the East China Sea: Implications for Biogeochemical Niche. Plant Soil 431, 273-288. doi:10.1007/s11104-018-3759-6

Hu, Q., Jiang, D., and Fan, G. (2015). Climate Change Projection on the Tibetan Plateau: Results of CMIP5 Models. Chin. J. Atmos. Sci. 39, 260-270. doi:10.3878/j.issn.1006-9895.1406.13325 (in Chinese).

Jiang, J., and Song, M. (2010). Review of the Roles of Plants and Soil Microorganisms in Regulating Ecosystem Nutrient Cycling. Chin. J. Plant Ecol. 34, 979-988. doi:10.1002/ece3.942 (in Chinese).

Jiang, L., He, Z., Liu, J., Xing, C., Gu, X., Wei, C., et al. (2019). Elevation Gradient Altered Soil C, N, and P Stoichiometry of Pinus Taiwanensis Forest on Daiyun Mountain. Forests 10, 1089. doi:10.3390/f10121089

Jing, H., Sun, N., UMAIR, M., Liu, C., and Du, H. (2020). Stoichiometric Characteristics of Soils and Dominant Shrub Leaves and Their Responses to Water Addition in Different Seasons in Degraded Karst Areas in Southern Yunnan of China. Chin. J. Plant Ecol. 44, 56-69. doi:10.17521/cjpe.2019.0230 (in Chinese).

Kissel, D. E., Sonon, L., Vendrell, P. F., and Isaac, R. A. (2009). Salt Concentration and Measurement of Soil pH. Commun. Soil Sci. Plant Anal. 40, 179-187. doi:10.1080/00103620802625377

Kleijn, D., and Müller-Schärer, H. (2006). The Relation between Unpalatable Species, Nutrients and Plant Species Richness in Swiss Montane Pastures. Biodivers. Conserv. 15, 3971-3982. doi:10.1007/s10531-005-3012-5

Koerselman, W., and Meuleman, A. F. M. (1996). The Vegetation N:P Ratio: A New Tool to Detect the Nature of Nutrient Limitation. J. Appl. Ecol. 33, 1441-1450. doi:10.2307/2404783

Li, F., Hu, J., Xie, Y., Yang, G., Hu, C., Chen, X., et al. (2018). Foliar Stoichiometry of Carbon, Nitrogen, and Phosphorus in Wetland Sedge Carex Brevicuspis along a Small-Scale Elevation Gradient. Ecol. Indicators 92, 322-329. doi:10.1016/ j.ecolind.2017.04.059

Li, R., Liu, Q., Li, D., Che, G., Zhao, M., and Niu, J. (2018). Ecological Stoichiometry of Degraded Leymus Chinensis Steppe in Xilin River Basin. Chin. J. Grassland 40, 75-80. doi:10.16742/j.zgcdxb.2018-02-12 (in Chinese).

Li, X., Gao, J., Brierley, G., Qiao, Y., Zhang, J., and Yang, Y. (2013). Rangeland Degradation on the Qinghai-Tibet Plateau: Implications for Rehabilitation. Land Degrad. Develop. 24, 72-80. doi:10.1002/ldr.1108

Li, Z., Tian, D., Wang, B., Wang, J., Wang, S., Chen, H. Y. H., et al. (2019). Microbes Drive Global Soil Nitrogen Mineralization and Availability. Glob. Change Biol. 25, 1078-1088. doi:10.1111/gcb.14557

Lin, C., Li, X., Zhang, J., Sun, H., and Ma, X. (2021). Effects of Degradation Succession of Alpine Wetland on Soil Organic Carbon and Total Nitrogen in the Yellow River Source Zone, West China. J. Mt. Sci. 18, 694-705. doi:10.1007/ s11629-020-6117-0

Liu, C., Liang, M., Nie, Y., Tang, J., and Siddique, K. H. M. (2019a). The Conversion of Tropical Forests to Rubber Plantations Accelerates Soil Acidification and Changes the Distribution of Soil Metal Ions in Topsoil Layers. Sci. Total Environ. 696, 134082. doi:10.1016/j.scitotenv.2019.134082

Liu, D., Zhang, J., Biswas, A., Cao, J., Xie, H., and Qi, X. (2020). Seasonal Dynamics of Leaf Stoichiometry of Phragmites Australis: A Case Study from Yangguan Wetland, Dunhuang, China. Plants 9, 1323. doi:10.3390/plants9101323

Liu, J., Fang, X., Tang, X., Wang, W., Zhou, G., Xu, S., et al. (2019b). Patterns and Controlling Factors of Plant Nitrogen and Phosphorus Stoichiometry across China's Forests. Biogeochemistry 143, 191-205. doi:10.1007/s10533-01900556-7

Liu, S. (1989). "Compositae (4)," in Editorial Board of Flora of China, Chinese Academy of Sciences, Flora of China (Beijing: Science Press), 70, 112-115. (in Chinese).
Liu, S., Gao, L., Pu, Y., Deng, L., and Zhang, S. (2005). Status of Soil P and K Nutrient and Their Influencing Factors in Tibet. J. Soil Water Conservation 19, 75-78. doi:10.3321/j.issn:1009-2242.2005.01.019 (in Chinese).

Liu, W., Qin, y., Xiaofang, Z., Adamowski, J. F., and Biswas, A. (2021). Leaf Stoichiometry of Potentilla Fruticosa across Elevations Ranging from $2400 \mathrm{M}$ to 3800 M in China's Qilian Mountains (Northeast Qinghai-Tibetan Plateau). Preprint. doi:10.21203/rs.3.rs-409649/v1

Liu, X., Cheng, Z., and Zhang, R. (2009). The A1B Scenario Projection for Climate Change over the Tibetan Plateau in the Next 30 50 Years. Plateau Meteorology 28, 475-484. doi:10.1016/S1003-6326(09)60084-4 (in Chinese).

Liu, Y., Ding, Z., Bachofen, C., Lou, Y., Jiang, M., Tang, X., et al. (2018). The Effect of Saline-Alkaline and Water Stresses on Water Use Efficiency and Standing Biomass of Phragmites Australis and Bolboschoenus Planiculmis. Sci. Total Environ. 644, 207-216. doi:10.1016/j.scitotenv.2018.05.321

Liu, Y., Wei, W., Wen, X., and Li, J. (2014). Distribution Study of Soil Organic Carbon Fraction on Degradation Alpine Grassland in the Source Area of Three Major Rivers of China. Chin. J. Soil Sci. 45, 13701376. doi:10.19336/ j.cnki.trtb.2014.06.013(in Chinese).

Liu, Z., Fu, B., Zheng, X., and Liu, G. (2010). Plant Biomass, Soil Water Content and Soil N:P Ratio Regulating Soil Microbial Functional Diversity in a Temperate Steppe: A Regional Scale Study. Soil Biol. Biochem. 42, 445-450. doi:10.1016/ j.soilbio.2009.11.027

Mcgroddy, M. E., Daufresne, T., and Hedin, L. O. (2004). Scaling of C:n:p Stoichiometry in Forests Worldwide: Implications of Terrestrial Redfieldtype Ratios. Ecology 85, 2390-2401. doi:10.1890/03-0351

Mulder, C., and Elser, J. J. (2009). Soil Acidity, Ecological Stoichiometry and Allometric Scaling in Grassland Food Webs. Glob. Change Biol. 15, 2730-2738. doi:10.1111/j.1365-2486.2009.01899.x

Müller, M., Oelmann, Y., Schickhoff, U., Böhner, J., and Scholten, T. (2017). Himalayan Treeline Soil and Foliar C:N:P Stoichiometry Indicate Nutrient Shortage with Elevation. Geoderma 291, 21-32. doi:10.1016/ j.geoderma.2016.12.015

Nelson, D., and Sommers, L. E. (1982). Methods of Soil Analysis. Part 2 Chem. Total Carbon, Organic Carbon, and Organic, 9. Hoboken: John Wiley \& Sons, 539-579.

Niu, Y., Kang, J., Su, H., Adamowski, J. F., Biswas, A., Liu, C., et al. (2021). Elevation Alone Alters Leaf N and Leaf C to N Ratio of Picea Crassifolia Kom. In China's Qilian Mountains. Forests 12, 1325. doi:10.3390/f12101325

Olsen, S. R. (1954). Estimation of Available Phosphorus in Soils by Extraction with Sodium Bicarbonate, 939. Washington: USDA Cicular.

Ouyang, Y., and Norton, J. M. (2020). Short-Term Nitrogen Fertilization Affects Microbial Community Composition and Nitrogen Mineralization Functions in an Agricultural Soil. Appl. Environ. Microbiol. 86, e02278-19. doi:10.1128/ AEM.02278-19

Parton, W. J., Stewart, J. W. B., and Cole, C. V. (1988). Dynamics of C, N, P and S in Grassland Soils: A Model. Biogeochemistry 5, 109-131. doi:10.1007/ BF02180320

Poorter, L., and Bongers, F. (2006). Leaf Traits Are Good Predictors of Plant Performance across 53 Rain Forest Species. Ecology 87, 1733-1743. doi:10.1890/ 0012-9658(2006)87[1733:Itagpo]2.0.co;2

Prescott, C. E., Chappell, H. N., and Vesterdal, L. (2000). Nitrogen Turnover in Forest Floors of Coastal Douglas-fir at Sites Differing in Soil Nitrogen Capital. Ecology 81, 1878-1886. doi:10.1890/0012-9658(2000)081[1878:ntiffo] 2.0.co;2

Qin, Y., Adamowski, J. F., Deo, R. C., Hu, Z., Cao, J., Zhu, M., et al. (2019). Controlling Factors of Plant Community Composition with Respect to the Slope Aspect Gradient in the Qilian Mountains. Ecosphere 10, e02851. doi:10.1002/ecs2.2851

Qin, Y., Feng, Q., Adamowski, J. F., Zhu, M., and Zhang, X. (2021). Community Level Response of Leaf Stoichiometry to Slope Aspect in a Montane Environment: A Case Study from the Central Qilian Mountains, China. Glob. Ecol. Conservation 28, e01703. doi:10.1016/j.gecco.2021.e01703

Reich, P. B., Oleksyn, J., and Tilman, G. D. (2004). Global Patterns of Plant Leaf N and P in Relation to Temperature and Latitude. Proc. Natl. Acad. Sci. 101, 11001-11006. doi:10.1073/pnas.0403588101

Reich, P. B., Tjoelker, M. G., Machado, J.-L., and Oleksyn, J. (2006). Universal Scaling of Respiratory Metabolism, Size and Nitrogen in Plants. Nature 439, 457-461. doi:10.1038/nature04282 
Reiners, W. A. (1986). Complementary Models for Ecosystems. The Am. Naturalist 127, 59-73. doi:10.1086/284467

Sanaullah, M., Rumpel, C., Charrier, X., and Chabbi, A. (2012). How Does Drought Stress Influence the Decomposition of Plant Litter with Contrasting Quality in a Grassland Ecosystem. Plant Soil 352, 277-288. doi:10.1007/s11104-011-0995-4

Sardans, J., Rivas-Ubach, A., and Peñuelas, J. (2011). Factors Affecting Nutrient Concentration and Stoichiometry of Forest Trees in Catalonia (NE Spain). For. Ecol. Manag. 262, 2024-2034. doi:10.1016/j.foreco.2011.08.019

Shi, G., Wang, W., Jiang, J., Cheng, G., Yao, B., Feng, H., et al. (2018). Effects of the Spreading of Ligularia Virgaurea on Soil Physicochemical Property and Microbial Functional Diversity. Chin. J. Plant Ecol. 42, 126-132. doi:10.17521/cjpe.2017.0111 (in Chinese).

Shi, X., Li, X., Wu, R., Yang, Y., and Long, R. (2011). Changes in Soil Biochemical Properties Associated with Ligularia Virgaurea Spreading in Grazed Alpine Meadows. Plant Soil 347, 65-78. doi:10.1007/s11104-011-0818-7

Silvertown, J. (2004). Plant Coexistence and the Niche. Trends Ecol. Evol. 19, 605-611. doi:10.1016/j.tree.2004.09.003

Su, H., Zhang, X., Niu, Y., Wang, H., and Cao, J. (2021). Effects of Altitude on Leaf Ecological Stoichiometry of Stellera Chamaejasme in the Qilian Mountains. J. Desert Res. 41, 205-212. doi:10.7522/j.issn.1000-694X.2021.00113 (in Chinese).

Sun, L., Gong, L., Zhu, M., Xie, L., Li, H., and Luo, Y. (2017a). Leaf Stoichiometric Characteristics of Typical Desert Plants and Their Relationships to Soil Environmental Factors in the Northern Margin of the Tarin Basin. Chin. J. Ecol. 36, 1208-1214. doi:10.13292/j.1000-4890.201705.021 (in Chinese).

Sun, L., Zhang, B., Wang, B., Zhang, G., Zhang, W., Zhang, B., et al. (2017b). Leaf Elemental Stoichiometry of Tamarix Lour. Species in Relation to Geographic, Climatic, Soil, and Genetic Components in China. Ecol. Eng. 106, 448-457. doi:10.1016/j.ecoleng.2017.06.018

Swift, M. J., Heal, O. W., and Anderson, J. M. (1979). Decomposition in Terrestrial Ecosystems. Stud. Ecol. 5, 2772-2774. doi:10.1063/1.1615673

Taylor, B. R., Parkinson, D., and Parsons, W. F. J. (1989). Nitrogen and Lignin Content as Predictors of Litter Decay Rates: A Microcosm Test. Ecology 70, 97-104. doi:10.2307/1938416

Timsina, B., Shrestha, B. B., Rokaya, M. B., and Münzbergová, Z. (2011). Impact of Parthenium Hysterophorus L. Invasion on Plant Species Composition and Soil Properties of Grassland Communities in Nepal. Flora - Morphol. Distribution, Funct. Ecol. Plants 206, 233-240. doi:10.1016/j.flora.2010.09.004

Tjoelker, M. G., Reich, P. B., and Oleksyn, J. (1999). Changes in Leaf Nitrogen and Carbohydrates Underlie Temperature and CO2acclimation of Dark Respiration in Five Boreal Tree Species. Plant Cel. Environ. 22, 767-778. doi:10.1046/j.13653040.1999.00435.x

Tori, M., Honda, K., Nakamizo, H., Okamoto, Y., Sakaoku, M., Takaoka, S., et al. (2006). Chemical Constituents of Ligularia Virgaurea and its Diversity in Southwestern Sichuan of China. Tetrahedron 62, 4988-4995. doi:10.1016/ j.tet.2006.02.078

Wang, J., Zheng, Y., Hu, H., Li, J., Zhang, L., Chen, B., et al. (2016). Coupling of Soil Prokaryotic Diversity and Plant Diversity across Latitudinal Forest Ecosystems. Sci. Rep. 6, 19561. doi:10.1038/srep19561

Wang, M., Zhao, Z., Du, G., and He, Y. (2008). Effects of Light on the Growth and Clonal Reproduction ofLigularia Virgaurea. J. Integr. Plant Biol. 50, 1015-1023. doi:10.1111/j.1744-7909.2008.00645.x

Wang, Y., Wang, B., Hou, Q., Su, X., Zhang, S., and Sun, K. (2018). Prezygotic Reproductive Isolation of Two Sympatric Species of Ligularia Weeds in Eastern Qinghai-Tibet Plateau, China. Ying Yong Sheng Tai Xue Bao 29, 3587-3595. doi:10.13287/j.1001-9332.201811.008 (in Chinese).

Wang, Y., Bao, Y., and Nan, S. (2019). Dynamic and Thermodynamic Effects on Climate Changes over the Qinghai-Tibetan Plateau in Response to Global Warming. Plateau Meteorology 38, 29-41. doi:10.7522/j.issn.10000534.2018.00066 (in Chinese).
Wu, J., Zhang, X., Shen, Z., Shi, P., Yu, C., Song, M., et al. (2012). Species Richness and Diversity of Alpine Grasslands on the Northern Tibetan Plateau: Effects of Grazing Exclusion and Growing Season Precipitation. J. Resour. Ecol. 3, 236-242. doi:10.5814/j.issn.1674-764x

Xu, X., Qin, Y., Cao, J., Li, M., Gong, Y., and Zhang, X. (2018). Elevational Variations of Leaf Stochiometry in Leontopodium Leontopodioides on the Qinghai-Tibetan Plateau, China. Ying Yong Sheng Tai Xue Bao 29, 3934-3940. doi:10.13287/j.1001-9332.201812.021 (in Chinese).

Xu, X., Qin, Y., and Cao, J. (2019). Variation Characteristics of Potentilla Bifurca Leaf Stochiometry along the Elevation Gradient on the Northeastern QinghaiTibetan Plateau. Acta Eco Sin 39, 9044-9051. doi:10.5846/stxb201805231128 (in Chinese).

Xue, X., You, Q., Peng, F., Dong, S., and Duan, H. (2017). Experimental Warming Aggravates Degradation-Induced Topsoil Drought in Alpine Meadows of the Qinghai-Tibetan Plateau. Land Degrad. Develop. 28, 2343-2353. doi:10.1002/ ldr.2763

Yan, Z., Kim, N., Han, W., Guo, Y., Han, T., Du, E., et al. (2015). Effects of Nitrogen and Phosphorus Supply on Growth Rate, Leaf Stoichiometry, and Nutrient Resorption of Arabidopsis thaliana. Plant Soil 388, 147-155. doi:10.1007/ s11104-014-2316-1

Yang, G., Xiao, D., and Zhou, L. (2004). Forest Landscape Pattern and its EcoHydrological Effects of the Qilian Mountains in Northwest China. Adv. Water Sci. 15, 489-494. doi:10.3321/j.issn:1001-6791.2004.04.016 (in Chinese).

Yang, H., and Wang, D. (2011). Advances in the Study on Ecological Stoichiometry in Grass-Environment System and its Response to Environment Factors. Acta Prataculturae Sinica 20, 244-252. doi:10.1631/ jzus.B1000275 (in Chinese).

Zhang, J., Xie, H., Biswas, A., Shan, Y., Qi, X., and Cao, J. (2021). Response of Different Organs' Stoichiometry of Phragmites Australis to Soil Salinity in Arid Marshes, China. Glob. Ecol. Conservation 31, e01843. doi:10.1016/ j.gecco.2021.e01843

Zhang, J., Zhao, N., Liu, C., Yang, H., Li, M., Yu, G., et al. (2017). C:N:P Stoichiometry in China's Forests: From Organs to Ecosystems. Funct. Ecol. 32, 50-60. doi:10.1111/1365-2435.12979

Zhao, C., Nan, Z., Cheng, G., Zhang, J., and Feng, Z. (2006). GIS-assisted Modelling of the Spatial Distribution of Qinghai Spruce (Picea Crassifolia) in the Qilian Mountains, Northwestern China Based on Biophysical Parameters. Ecol. Model. 191, 487-500. doi:10.1016/j.ecolmodel.2005.05.018

Zhao, S., Li, J., Sun, X., Zeng, D., and Hu, Y. (2018). Responses of Soil and Plant Stoichiometric Characteristics along Rainfall Gradients in Mongolian Pine Plantations in Native and Introduced Regions. Acta Eco. Sin. 38, 7189-7197. doi:10.5846/stxb201709131649 (in Chinese).

Conflict of Interest: The authors declare that the research was conducted in the absence of any commercial or financial relationships that could be construed as a potential conflict of interest.

Publisher's Note: All claims expressed in this article are solely those of the authors and do not necessarily represent those of their affiliated organizations, or those of the publisher, the editors, and the reviewers. Any product that may be evaluated in this article, or claim that may be made by its manufacturer, is not guaranteed or endorsed by the publisher.

Copyright ( $2022 \mathrm{Su}, \mathrm{Cui}$, Adamowski, Zhang, Biswas and Cao. This is an openaccess article distributed under the terms of the Creative Commons Attribution License (CC BY). The use, distribution or reproduction in other forums is permitted, provided the original author(s) and the copyright owner(s) are credited and that the original publication in this journal is cited, in accordance with accepted academic practice. No use, distribution or reproduction is permitted which does not comply with these terms. 